\title{
SIMULASI PENERAPAN PERBENDAHARAAN DESAIN FRANCIS D. K. CHING MENGENAI WUJUD DASAR PADA DESAIN ARSITEKTUR RUMAH TINGGAL TIPE 36
}

\author{
Moh. Saiful Hakiki ${ }^{1}$ \\ 1Prodi Arsitektur Universitas Merdeka Surabaya, email: saifulhakiki2017@gmail.com
}

\begin{abstract}
Home is where we take shelter, as one of the architectural works. Meanwhile, according to Ching (2000), there is a substantial and eternal design repertory that is when designer is familiar with the design repertory, henceforth a connection can be made between form and space with meaning. This study aims to simulate one of Ching's design repertories, namely the Basic Form, in the type 36 residential design on a $6 \times 12$ square meter site area. As a research with the Constructivism paradigm, this research is one of the interpretations of the repertory of this design in order to obtain the results of the design object. The results of this study are that the Basic Form is suitable for application to simple house designs (type 36) because it is used for simple design objects. The Basic Form is suitable to be applied to the design of residential facades on residential blocks because there will be variations in facade between one house and another. Then, the design of house type 36 using this Basic Model, as a simulation that was not actually designed in the real world, needs further research, specifically related to the practicality of production.
\end{abstract}

Keywords: Design Simulation, Constructivism, House Architecture, Basic Form

\begin{abstract}
Abstrak
Rumah tinggal merupakan tempat kita bernaung, dan juga merupakan hasil karya arsitektur. Sementara menurut Ching (2000), terdapat perbendaharaan desain yang bersifat substansial serta abadi, di mana apabila seorang perancang familiar dengan perbendaharaan desain tersebut, maka untuk selanjutnya dapat membentuk hubungan antara bentuk dan ruang dengan makna. Tujuan dari penelitian ini yaitu untuk mensimulasikan salah satu perbendaharaan desain Ching yaitu Wujud Dasar, pada desain rumah tinggal tipe 36 di lahan berukuran $6 \times 12$ meter persegi. Sebagai penelitian dengan paradigma Konstruksivisme, penelitian ini adalah salah satu interpretasi dari perbendaharaan desain tersebut sehingga hasil yang didapatkan adalah berupa penerapan desain dari obyek rancang. Hasil dan pembahasan penelitian ini yaitu bahwa Wujud Dasar sesuai jika diterapkan pada desain rumah tinggal sederhana (tipe 36) dikarenakan wujud yang mendasar sesuai dengan obyek rancang yang bersifat sederhana. Selain itu, Wujud Dasar sesuai jika diterapkan pada desain fasad rumah tinggal pada blok perumahan dikarenakan akan terdapat variasi fasad antara rumah satu dengan rumah lain. Kemudian, sebagai simulasi yang tidak benar-benar dibangun di dunia nyata, desain rumah tinggal sederhana tipe 36 dengan menerapkan Wujud Dasar ini memerlukan pengkajian lebih lanjut, terutama yang berkaitan dengan kepraktisan manufaktur.
\end{abstract}

Kata-kunci : Simulasi Desain, Konstruksivisme, Arsitektur Rumah Tinggal, Wujud Dasar

\section{Pendahuluan}

Pertumbuhan lahan untuk perumahan tidak bisa dipungkiri merupakan kebutuhan bagi masyarakat. Dibangunnya rumah-rumah baru dengan desain custom maupun didesain massal oleh pengembang, pada saat ini merupakan potensi bagi arsitek untuk dapat turut berkarya merancang lingkung bina yang baik, menghasilkan obyek rancang arsitektur yang estetis dan memiliki kesesuaian dengan konteks di mana bangunan tersebut berada. Kebutuhan akan rumah tinggal ini dinyatakan oleh Sitorus dalam Julianto (2016), bahwa hingga tahun 2025 kebutuhan akan rumah tinggal di Indonesia diperkirakan akan berjumlah lebih dari 30 juta unit, dan kebutuhan akan rumah tinggal mencapai 1,2 juta buah per tahun.

Sebagaimana pernyataan Ballantyne (2002), bahwa rumah tidak bisa dipisahkan dengan makna, karena rumah merupakan awal dari pengetahuan seorang manusia, dan banyak sekali terlibat dengan aspek personal dari hidup kita. 
"Kita berada di rumah ketika sedang sakit dan tak berdaya, begitu pula melalui rumah kita menunjukkan fasad atau tampak muka yang ingin kita perlihatkan pada dunia luar. Rumah bersama kita di saat-saat terburuk, menaungi dan melindungi kita sehingga kita merasa aman dan memiliki perasaan kuat kembali, walaupun perasaan itu tidak disadari di sebagian besar waktu. Perasaan tersebut juga dapat disematkan pada tempat lain, dan tempat lain tersebut dapat berkontribusi pula pada perasaan seperti di rumah (the feeling of being at home)". (Ballantyne, 2002)

Sebagai satu dari obyek rancang arsitektur, perancangan oleh arsitek dari sebuah rumah tinggal juga tidak hanya untuk rumah berukuran besar atau mewah, namun juga diperuntukkan bagi rumah berukuran sederhana, di mana arsitektur juga dapat diterapkan untuk obyek rancang sederhana.

Menurut Ballantyne (2002), arsitektur seringkali dikatakan sebagai bangunan yang impresif, sehingga bangunan yang tidak impresif disebut sebagai hanya "bangunan", bukan "arsitektur", namun "arsitektur" tidaklah sama dengan apa yang disebut sebagai "bangunan yang bagus". Bangunan adalah bagaimana semua material dirakit/disatukan, namun gestur bangunan (keberlimpahan, eksotisme, serta kemewahan) termasuk juga dalam porsi arsitektur. Ballantyne menyatakan bahwa arsitektur diperoleh melalui cara hidup, dan kita memperoleh kesimpulan tentang hidup dari mengintrepretasikan arsitektur. Secara dua arah, kita dapat memilih untuk hidup di lingkungan yang merefleksikan ide kita tentang siapa kita, atau orang lain yang mengamati kita yang hidup dalam suatu kondisi dan mereka mengungkap lebih banyak dari pegnetahuan kita sebelumnya tentang diri sendiri.

Dalam perancangan arsitektur menurut Vitruvius, pada Atmadjaja dan Dewi (1999), terdapat tiga aspek utama yaitu aspek fungsi, struktur dan estetika di mana ketiganya saling berkait dan saling menunjang satu dengan yang lainnya membentuk satu kesatuan arsitektur secara utuh. Menurut Atmadjaja dan Dewi (1999), secara umum arsitektur sebagai hasil desain merupakan karya visual/rupa yang diwujudkan melalui proses pemecahan masalah terhadap suatu kondisi tertentu, di mana wujud akhir dari proses desain ini adalah sebuah bentuk arsitektur.

Ching (2000) menyatakan bahwa bentuk dan ruang adalah piranti penting arsitektur yang terdiri dari perbendaharaan desain yang bersifat substansial serta abadi. Ching (2000) juga menyarankan bahwa setelah familiar dengan elemen dan prinsip-prinsip pada perbendaharaan desain, maka hubungan dengan makna dari sebuah bentuk dan ruang dapat dibentuk.

Kemudian Alexander (1973) menyatakan bahwa individualitas adalah ciri utama dari kesadaran diri (selfconsciousness) pada arsitek. Arsitektur yang telah berubah menjadi disiplin selfconscious memiliki ciri di mana para arsitek ingin sekali membedakan dirinya dengan arsitek lain, membuat inovasi dan menjadi bintang. Arsitek pada kondisi selfconscious ingin dapat menemukan bentuk sendiri, dan keberhasilan dalam proses pembuatan bentuk bagi arsitek adalah pencapaian diri.

Karena itu, upaya yang dilakukan di dalam penelitian ini adalah pembuatan bentuk yang didasarkan pada Wujud Dasar agar dapat dilakukan simulasi dari proses pembuatan bentuk yang eksplisit, sesuai pernyataan Alexander (1973) bahwa proses pembelajaran yang bersifat formal dan eksplisit merupakan salah satu ciri dari kebudayaan selfconscious. Dari simulasi ini diharapkan akan tercapai hasil rancang yang unik atau bersifat individualistis dan dapat menjadi referensi bagi praktisi serta akademisi di bidang perancangan arsitektur.

Simulasi dilakukan pada desain rumah tinggal tipe 36, dikarenakan memiliki denah yang sederhana, agar penelitian dapat terfokus pada pembuatan bentuk, dan juga agar dapat menjadi referensi untuk desain rumah tinggal sederhana tipe 36 pada perumahan yang memiliki lahan persegi seluas $6 \times 12$.

Batasan permasalahan yang akan dikaji pada penelitian ini sebagai berikut:

1. Perbendaharaan desain pada Arsitektur: Bentuk, Ruang dan Tatanan oleh FDK Ching dikhususkan pada Wujud Dasar.

2. Simulasi diterapkan pada fasad bangunan yang berprngaruh pula pada bentuk bangunan secara keseluruhan.

3. Penerapan perbendaharaan desain pada Arsitektur: Bentuk, Ruang dan Tatanan untuk simulasi rancangan rumah tinggal tipe 36 yang terdiri dari 1 ruang multifungsi, dua kamar tidur, satu kamar mandi, teras, carport, halaman depan dan halaman belakang.

\section{Tujuan Penelitian}

Menurut Groat dan Wang (2013), pertanyaan penelitian berhubungan dengan faktor eksternal (kontekstual) yaitu apa yang menjadi motivasi dari sebuah studi, kemudian siapa yang menjadi audiens, dan apa manfaat atau dampak positifnya. Selain itu, terdapat juga tujuan internal dari penelitian yaitu apakah ditujukan untuk pembangunan teori atau untuk aplikasi/penerapan. 
Tujuan penelitian ini yaitu untuk mengaplikasikan perbendaharaan desain bentuk, ruang dan tatanan dari Ching (2000), khususnya mengenai Wujud Dasar, sebagai satu bentuk eksplorasi dari solusi atas masalah desain arsitektur, khususnya rumah tinggal sederhana.

Sementara motivasi penelitian ini yaitu untuk memberikan sumbangsih di area perancangan arsitektur mengenai sebuah alternatif penerapan perbendaharaan desain, juga selain itu dikarenakan pada kondisi empiris masih belum ada penjelasan khusus penerapan Wujud Dasar pada rumah tinggal sederhana, di mana keduanya memiliki kesederhanaan di dalam tampilan bentuknya. Begitu pula pada ranah penelitian, diharapkan dapat menjadi sumbangsih penelitian perancangan arsitektur khususnya penerapan dari perbendaharaan desain pada sebuah obyek rancang.

Penelitian ini diharapkan untuk menjadi referensi mengenai proses desain yang eksplisit baik bagi praktisi maupun akademisi di bidang arsitektur. Dan juga sebagai referensi studi desain rumah tinggal sederhana tipe 36.

Dampak positif dari penelitian ini, diharapkan dapat memperkaya ide-ide desain baru yang akan muncul dari ranah praktis maupun akademis, sehingga kreativitas dapat semakin berkembang di area perancangan arsitektur, secara khusus di Indonesia.

\section{Tinjauan Pustaka}

Menurut Ching (2000) perbendaharaan desain yang dimiliki perancang mempengaruhi persepsi terhadap pertanyaan maupun bentuk jawaban solusi yang akan diberikan. Jika pemahaman mengenai bahasa perancangan terbatas, maka jangkauan atas solusi-solusi yang mungkin diterapkan untuk masalah itu akan terbatas juga.

Sementara menurut Darmawan dan Maharani (2016), perancangan arsitektur selalu diawali dengan manusia-nya: keinginannya, kegiatannya, agar dapat menentukan peranan, struktur organisasi, profil pengguna, dan deskripsi lainnya, sehingga dapat ditentukan bentuk arsitektur dan karakternya, serta tercipta bangunan yang nyaman dan aman untuk dihuni serta tidak merugikan alam.

Menurut Herbert Simon dalam Groat dan Wang (2013) tindakan merancang adalah ditujukan untuk mengubah situasi yang ada menjadi lebih disukai. Sementara Nigel Cross menyatakan bahwa fokus utama semua kegiatan desain adalah deskripsi tentang seperti apa artefak baru yang diinginkan itu seharusnya. Desain mendorong pengembangan artefak yang dirancang sebagai solusi yang diharapkan akan dapat dicapai di masa depan.

Sedangkan menurut Alexander (1973) Desain yang baik dapat dicapai apabila tidak ada ketidaksesuaian (misfits) sehingga tercapai kesesuaian (good fit), di mana yang dimaksud adalah bahwa desain merupakan proses menyelesaikan masalah (problem so/ving).

Dalam penelitian ini, proses desain dilakukan berdasarkan perbendaharaan desain, serta kesesuaian dengan dimensi, skala dan kebutuhan ruang manusianya, serta berupaya untuk mencapai bentuk yang disukai dalam arti terkonsep dan sesuai dengan rencana yang dibuat, sehingga terdapat kesesuaian ( good fit) yang diinginkan, pada obyek rancang rumah tinggal tipe 36 di atas lahan $6 \times 12$ meter persegi.

Dari Tujuan Umum Penelitian, Tujuan Kontekstual dan Tinjauan Pustaka, maka diperoleh pertanyaan penelitian sebagai berikut:

1. Apa sajakah yang menjadi perbendaharaan desain Wujud Dasar dari Francis D.K. Ching?

2. Bagaimana penerapan dari perbendaharaan desain Wujud Dasar pada desain Rumah Tinggal Tipe 36 di atas lahan $6 \times 12$ meter persegi?

3. Apa saja pembahasan dari penerapan perbendaharaan desain tersebut dari masing-masing alternatif desain yang akan muncul?

\section{Metode}

Berdasarkan pengelompokan paradigma penelitian oleh Groat dan Wang (2013), penelitian ini dapat dimasukkan ke dalam kelompok paradigma penelitian Konstruksivisme di mana penelitian bersifat subyektif, memandang bahwa pengetahuan bersifat sementara dan berubah-ubah, serta terdapat realita yang bersifat relatif dalam jumlah tak terbatas. Menurut Groat dan Wang, pada penelitian Konstruksivisme, desain arsitektur merupakan subyek interpretasi dan reinterpretasi, di mana interpretasi selalu bersifat sementara serta cair. Pada penelitian ini, interpretasi dilakukan terhadap perbendaharaan desain Wujud Dasar oleh Ching (2000) untuk diaplikasikan pada desain rumah tinggal sederhana tipe 36. 
Jurnal Arsitektur AIVR - Vol 4 No 1 Mei 2021

e-ISSN 2685-1490; p-ISSN 2615-1472

Penelitian yang bersifat subyektif sesuai dengan pendapat Kant di dalam Crysler et al (2012) mengenai estetika, yaitu bahwa estetika pada dasarnya bersifat subyektif dan ada dalam penilaian rasa. Crysler et al menyatakan bahwa estetika merupakan studi tentang refleksi kita pada kesenangan atau ketidaksenangan dari suatu pengalaman yang bersifat indrawi.

Diagram yang merupakan penyesuaian dari diagram Groat dan Wang (2013) menunjukkan proses Kerangka Berpikir penelitian di mana di dalamnya terdapat penentuan Tujuan Kontekstual/ Eksterna, terdiri dari Motivasi penelitian, Audiens dari penelitian serta Dampak positif yang diharapkan timbul dengan adanya penelitian ini. Kemudian juga terdapat Tujuan Penelitian secara internal, yaitu sebagai aplikasi dari penafsiran/interpretasi terhadap perbendaharaan desain Wujud Dasar oleh Ching (2000). Dan juga terdapat Tinjauan Pustaka, di mana dilakukan tinjauan terhadap sumber-sumber kepustakaan mengenai topik terkait.

Setelah menentukan Tujuan Kontekstual, Tujuan Penelitian dan Tinjauan Pustaka, maka langkah selanjutnya yaitu menentukan pertanyaan penelitian dan juga strategi serta taktik penelitian, yaitu simulasi untuk penerapan perbendaharaan desain pada obyek rancang.

\section{Metode Pengumpulan Data}

Proses perancangan di dalam penelitian ini tidaklah nyata dan bertujuan untuk mengeksplorasi penerapan Wujud Dasar berdasarkan perbendaharaan desain dari Ching (2000), sehingga diharapkan akan dapat diperoleh banyak alternatif desain tanpa mengeluarkan biaya sebanyak ketika alternatif-alternatif tersebut dibangun secara nyata. Dengan simulasi diharapkan tujuan penelitian akan dapat dicapai.

\section{Metode Analisis Data}

Dari penjelasan di atas, diperoleh diagram dari metode penelitian di mana Paradigma Penelitian berpengaruh terhadap Kerangka Berpikir dalam penelitian. Salah satu unsur dari Kerangka Berpikir yaitu Strategi Penelitian. Strategi dalam penelitian ini adalah Simulasi. Menurut Groat dan Wang (2013), Simulasi adalah salinan dari kenyataan, di mana keunggulan dari simulasi ini adalah peneliti dapat mensimulasikan sebuah obyek arsitektur tanpa perlu mengeluarkan biaya untuk benar-benar membangunnya.

Kemudian juga, dengan adanya strategi simulasi pada penelitian, maka dimungkinkan penggunaan teknologi dalam aplikasinya sehingga diharapkan dapat diperoleh salinan kenyataan sesuai dengan obyek rancang yang dibangun di dunia nyata, dari sisi ukuran atau dimensi dan penerapan material solid dan transparan. Simulasi desain di dalam penelitian ini menggunakan bantuan software CAD (Computer Aided Design) dua dimensi dan tiga dimensi, yaitu AutoCAD dan Sketchup. Desain dua dimensi terdiri atas gambar denah dan alternatif-alternatif fasad, sedangkan desain tiga dimensi terdiri atas gambar isometri dan juga gambar tampak depan secara perspektif. 
Jurnal Arsitektur AIUR - Vol 4 No 1 Mei 2021

e-ISSN 2685-1490; p-ISSN 2615-1472

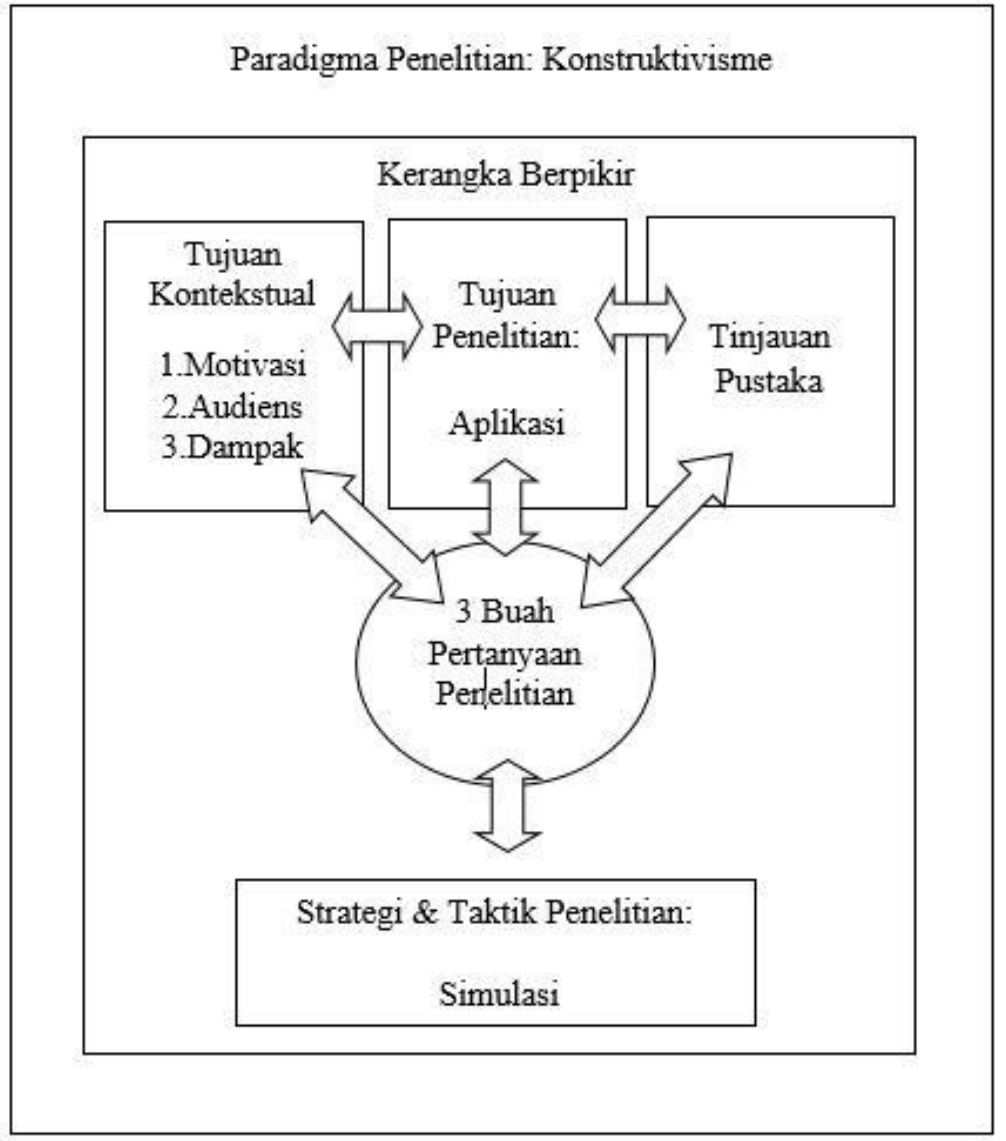

Gambar 1. Kerangka Penelitian (Penyesuaian dari Diagram Groat dan Wang, 2013) Sumber: Peneliti

\section{Hasil dan Pembahasan}

Wujud Dasar berdasarkan Ching (2000) terdapat di Gambar 2, terdiri atas lingkaran, segitiga dan bujursangkar.

Ching (2000) menyatakan sifat-sifat dari Wujud Dasar Lingkaran, Segitiga serta Bujursangkar di antaranya:

1. Lingkaran adalah figur yang bersifat memusat, introvert, yang pada keadaan normal bersifat stabil serta memiliki titik tengah sendiri di dalam lingkungannya. Lingkaran yang diletakkan di tengahtengah sebuah bidang akan bersifat memusat. Sedangkan bila lingkaran dihubungkan dengan bentuk-bentuk lurus ataupun bersudut di sepanjang kelilingnya, maka kondisi tersebut dapat menyebabkan gerakan berputar.

2. Segitiga merupakan wujud yang menekankan stabilitas. Jika diletakkan pada salah satu sisi sisinya, wujud segitiga merupakan wujud yang sangat stabil. Namun, jika segitiga berdiri di salah satu titik sudutnya, wujud tersebut akan seimbang dalam kondisi labil maksimum atau bisa juga memiliki kecenderungan jatuh ke salah satu sisinya.

3. Bujursangkar melambangkan sifat rasional dan murni. Merupakan wujud simetris dan memiliki dua sumbu tegak lurus serta sama panjangnya. Seperti segitiga, bujursangkar akan stabil jika diletakkan pada salah satu sisinya serta menjadi dinamis ketika berdiri di atas salah satu sudutnya. Ketika garis diagonal dari bujursangkar menjadi vertikal dan horisontal, wujud tersebut akan berada di dalam kondisi puncak keseimbangannya.

Hampir sama dengan Wujud Dasar pada Ching (2000), terdapat metode desain Quadrature dan Triangulasi di mana metode desain tersebut dinyatakan oleh Jormakka et al (2014) sebagai metode matematis untuk menentukan luas bidang dengan membagi bidang segi empat dan segitiga menjadi 
Jurnal Arsitektur AIUR - Vol 4 No 1 Mei 2021

e-ISSN 2685-1490; p-ISSN 2615-1472

kumpulan bentuk. Di Gambar 3 terlihat juga bahwa wujud bujursangkar yang diputar membentuk wujud lingkaran.

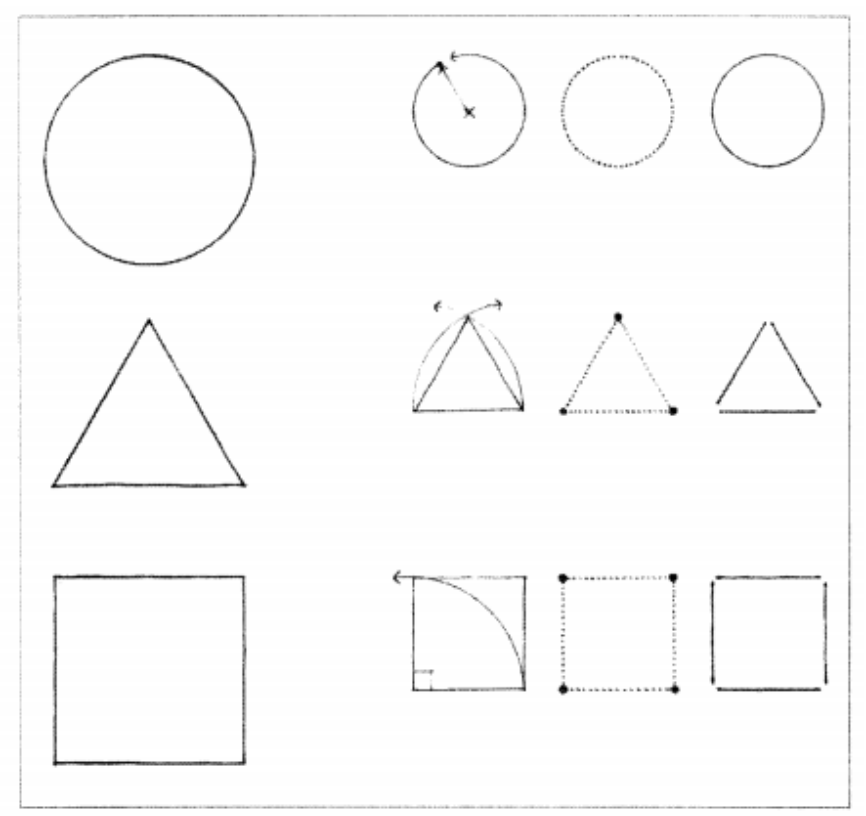

Gambar 2. Wujud-Wujud Dasar Sumber: Ching, 2000

Jormakka et al (2014) juga menyatakan bahwa suatu metode bukanlah mesin untuk memecahkan permasalahan arsitektur secara otomatis: ia berfokus pada metode, tetapi tidak membatasi pekerjaan sesungguhnya yaitu untuk memecahkan permasalahan desain. Sehingga Wujud Dasar pada proses rancang rumah tipe 36 ini tetap disesuaikan berdasarkan kebutuhan akan ruang di sebuah rumah tinggal sederhana dengan lahan terbatas.

Di dalam penelitian ini, Wujud Dasar diaplikasikan pada fasad dan bentuk bangunan. Alternatifalternatif wujud lingkaran pada fasad rumah tinggal tipe 36 beserta kode dan penjelasannya, antara lain yaitu:

1. Lingkaran netral (L1), yaitu suatu kondisi di mana lingkaran dalam berada di tengah-tengah dari bidang lingkaran luar.

2. Lingkaran stabil (L2), yaitu suatu kondisi di mana lingkaran dalam berada di bagian bawah dari bidang lingkaran luar.

3. Lingkaran tidak stabil (L3), yaitu suatu kondisi di mana lingkaran dalam yang berada di bagian samping dari bidang lingkaran luar.

4. Lingkaran puncak keseimbangan (L4), yaitu suatu kondisi di mana lingkaran dalam yang berada di bagian atas dari bidang lingkaran luar.

5. Lingkaran stabil di tengah bujursangkar (L5). Lingkaran dalam berada di pusat/tengah-tengah dari sebuah bidang bujursangkar.

6. Lingkaran sebagai swa-pusat di bidang bujursangkar (L6). Lingkaran dalam berada memusat di samping pada sebuah bidang bukursangkar.

7. Lingkaran dinamis di bidang bujursangkar (L7). Lingkaran berada pada bidang miring di bidang bujursangkar sehingga terkesan bergerak.

8. Lingkaran menetap di tempat dikelilingi sisi-sisi bujursangkar (L8). Lingkaran terpotong oleh sisi-sisi bidang bujursangkar. 
Jurnal Arsitektur AIUR - Vol 4 No 1 Mei 2021

e-ISSN 2685-1490; p-ISSN 2615-1472
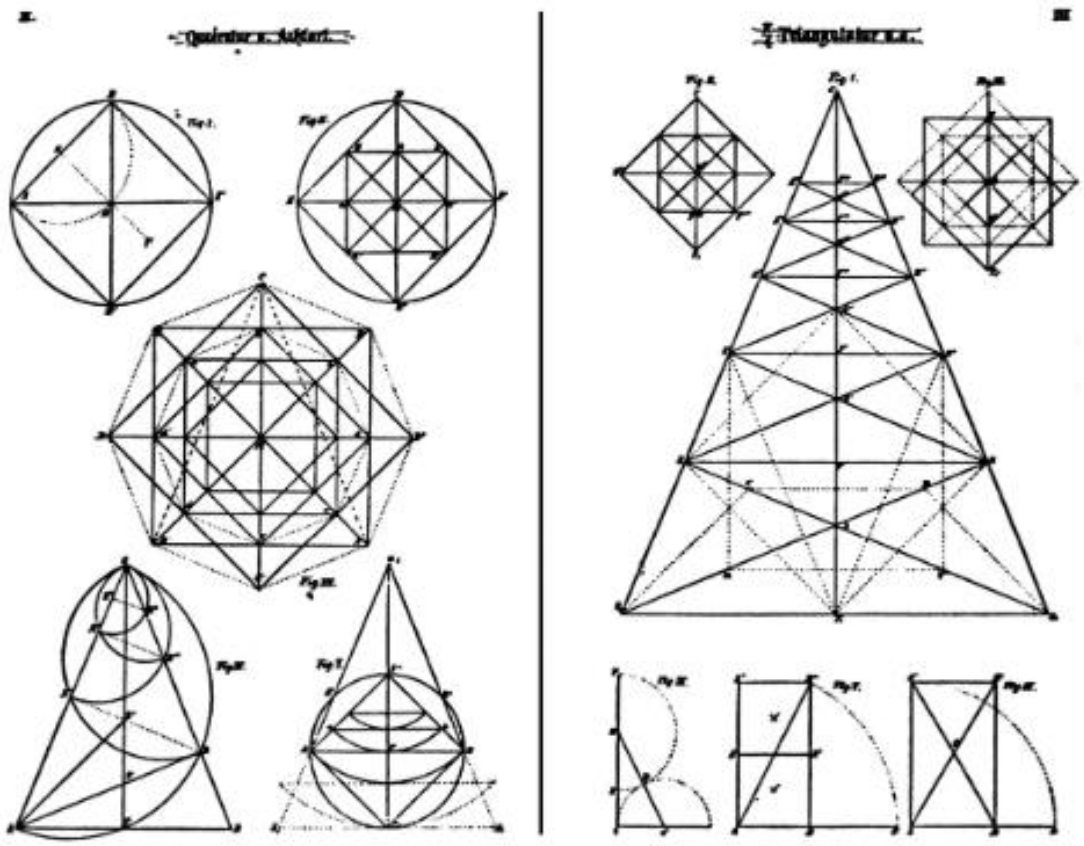

Gambar 3. Quadrature dan Triangulasi menurut Hendrik Petrus Berlage Sumber: Jormakka et al, 2014

Alternatif-alternatif wujud segitiga:

1. Segitiga stabil (S1). Segitiga berdiri secara stabil pada salah satu sisinya.

2. Segitiga labil maksimum (S2). Segitiga berdiri tegak secara terbalik dengan bertumpu di salah satu sudutnya.

3. Segitiga cenderung jatuh ke salah satu sisi (S3). Segitiga berdiri secara miring bertumpu ke salah satu sisinya.

Alternatif-alternatif Wujud Dasar bujursangkar:

1. Bujursangkar stabil (B1). Bujursangkar berdiri secara stabil pada salah satu sisinya.

2. Bujursangkar pada puncak keseimbangan (B2). Bujursangkar diputar 45 derajat dan bertumpu ke salah satu sudutnya.

3. Bujursangkar yang cenderung jatuh ke salah satu sisinya (B3). Bujursangkar berdiri secara miring bertumpu di salah satu sisinya.

Alternatif-alternatif pada masing-masing Wujud Dasar merupakan interpretasi dari perbendaharaan desain yang dinyatakan oleh Ching (2000) dalam teorinya pada Arsitektur: Bentuk, Ruang dan Tatanan di mana masing-masing merupakan perwujudan dari sifat-sifat masing-masing Wujud Dasar yang diterapkan di dalam desain arsitektur.

Alternatif diterapkan pada fasad dan bentuk bangunan dengan mempertimbangkan kebutuhan akan ruang di lahan terbatas dan juga obyek rancang rumah tinggal sederhana. Selain hal tersebut, juga terdapat kebutuhan akan pintu dan jendela yang juga menjadi pertimbangan dalam menerapkan Wujud Dasar. Pintu digambarkan dapat menjadi perpaduan antara bentuk solid dan transparan, sementara jendela digambarkan dibagi-bagi ke dalam bentuk lebih kecil dikarenakan kebutuhan akan perbedaan fungsi di dalam jendela, yaitu terdapat jendela yang dapat dibuka-tutup dan juga terdapat jendela dengan kaca mati.

Denah dari rumah tinggal tipe 36 pada lahan $6 \times 12$ meter persegi untuk masing-masing alternatif dibuat sama dengan yang terdapat pada Gambar 4. Dimana terdapat penyesuaian pada jendela depan, jendela belakang dan bentuk teras yang menyesuaikan Wujud Dasar yang digunakan.

Di Gambar 4 juga diterapkan penempatan furniture agar terdapat gambaran mengenai pembagian ruang dan juga fungsi/futniture yang diperkirakan dapat dimasukkan ke dalam ruangan tertentu. Khususnya pada Ruang Multifungsi di mana kebutuhannya adalah untuk Ruang Keluarga/Ruang Tamu dan Dapur serta 
Jurnal Arsitektur ALUR - Vol 4 No 1 Mei 2021

e-ISSN 2685-1490; p-ISSN 2615-1472

kebutuhan untuk meletakkan Kulkas dan Mesin Cuci sehingga aktivitas sehari-hari dapat dijalankan dengan baik di rumah dengan lahan terbatas tersebut.

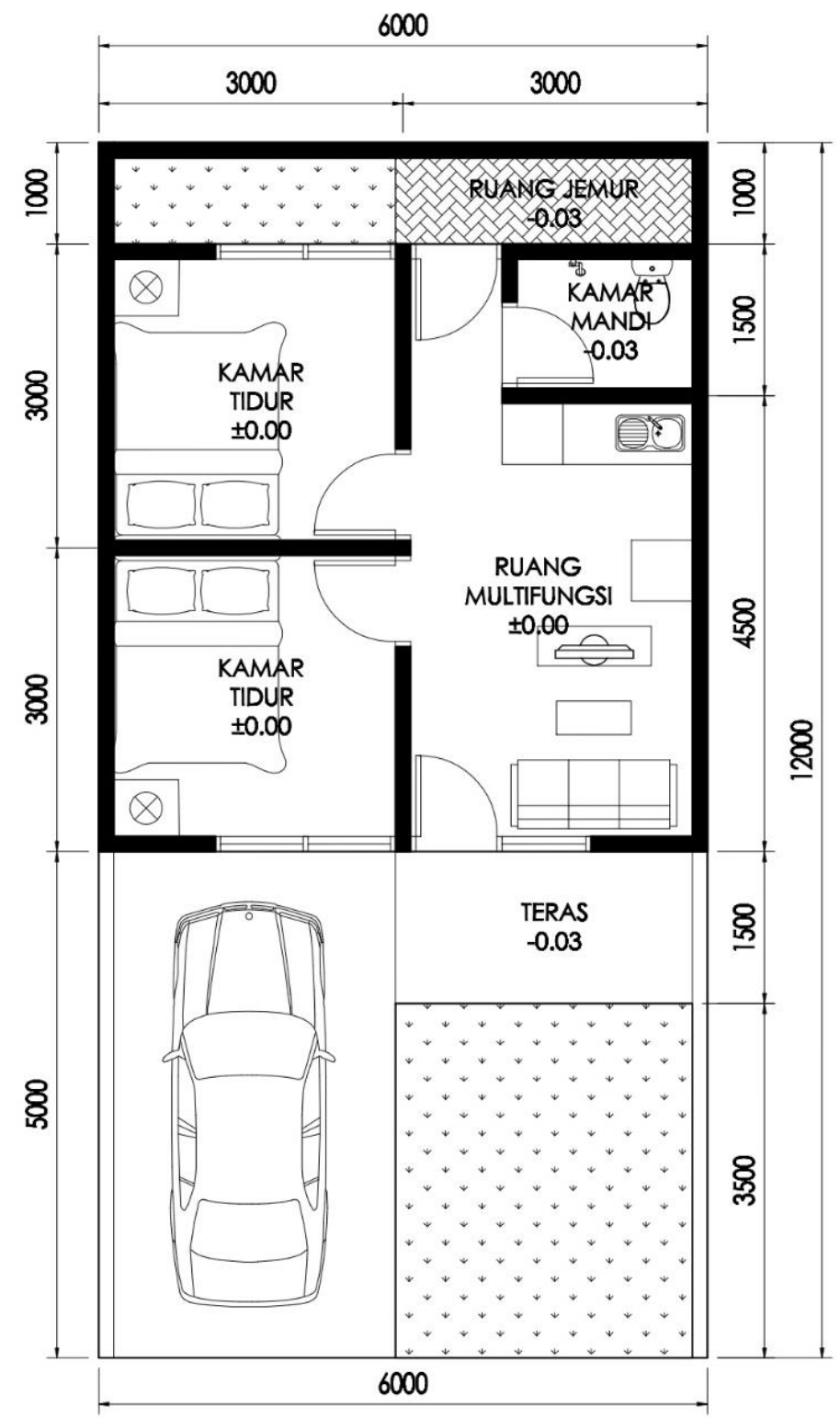

Gambar 4. Denah Rumah Tipe 36 Sumber: Peneliti

Seperti terlihat di Gambar 5, yaitu tampak depan perspektif untuk alternatif L1 (Lingkaran Netral), komposisi menyesuaikan dengan keberadaan pintu dan jendela. Begitu pula pada jendela, terdapat pembagian di mana ada daun jendela yang dapat dibuka dan ada jendela dengan kaca mati. Terdapat pula dinding pemisah pada tengah-tengah bidang fasad. Dinding pemisah tersebut berfungsi sebagai kolom pertemuan dinding fasad dengan dinding interior pemisah ruang multifungsi dengan kamar tidur. 


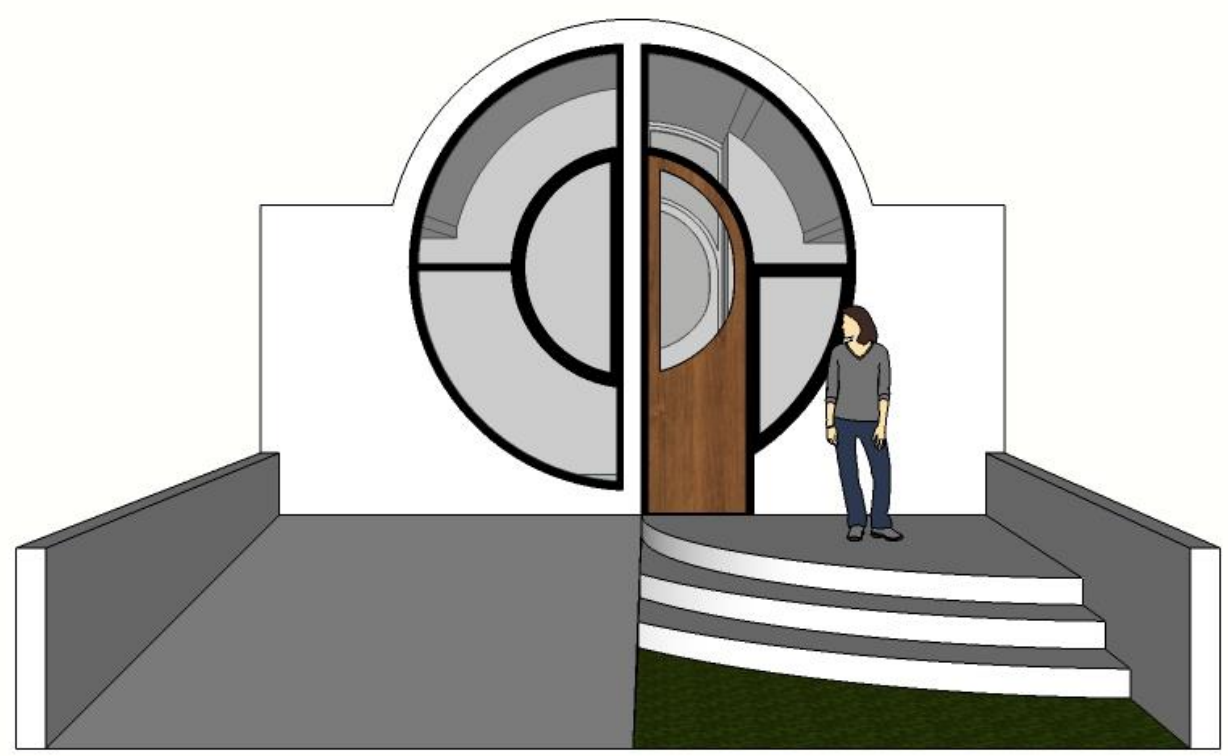

Gambar 5. Perspektif Tampak Depan L1 Sumber: Peneliti

Keterangan Gambar 5, yaitu bahwa pada Perspektif Tampak Depan di atas juga terdapat perbandingan skala manusia terhadap bangunan, di mana pada perbandingan tersebut diharapkan dapat dilihat perbandingan antara ukuran standar manusia terhadap bentuk bangunan, dimensi pintu dan juga ketinggian jendela yang berfungsi swing (dapat dibuka-tutup).

Selanjutnya di Gambar 6 yaitu Isometri, terdapat gambar isometri dengan penutup atap, dan juga tanpa penutup atap untuk memperlihatkan konfigurasi interior dalam ruang. Pada gambar isometri dengan atap, terlihat bahwa bentuk atap mengikuti bentuk fasad sehingga tidak terdapat wujud lain pada bangunan selain Wujud Dasar pada fasad. Sementara pada gambar isometri tanpa atap, terlihat bahwa dinding interior juga mengikuti bentuk fasad depan.

Di gambar isometri juga terlihat bahwa bentuk teras menyesuaikan dengan Wujud Dasar pada fasad dikarenakan agar terdapat kesatuan (unity) di dalam desain rumah tersebut. Sementara pada fasad, terdapat tambahan dinding setinggi 2,5 meter pada bagian kanan dan kiri agar ruang pada bagian tersebut dapat difungsikan dikarenakan lahan yang terbatas. Karena itu, Wujud Dasar pada fasad desain rumah tipe 36 ini ditampilan dalam komposisi pintu-jendela, dan bukan pada seluruh bentuk bangunan/ siluet bangunan, melainkan hanya pada sebagian saja dari keseluruhan bentuk bangunan. Gambar 7.

Untuk Wujud Dasar L1, L2 dan seterusnya, ditampilkan hasil desain dalam gambar 2D, terdapat pada

Pada desain penerapan Wujud Dasar L1-L4, terdapat komposisi wujud lingkaran di dalam lingkaran. Lingkaran luar diinterpretasikan mewujud pada bentukan atap lengkung, sedangkan lingkaran dalam mewujud pada bentuk kusen dan perbedaan material pada pintu (pintu digambarkan pada bentukan dengan blok abu-abu, sementara kaca digambarkan berwarna putih). Lingkaran dalam pada bidang lingkaran luar pada masing-masing desain berada di tengah-tengah, di bawah, di samping dan di atas sesuai penerapan perbendaharaan Ching (2000). Garis tebal pada jendela diperuntukkan untuk jendela swing yang dapat dibuka-tutup, sementara jendela dengan garis tipis merupakan jendela dengan kaca mati. 
Jurnal Arsitektur AIUR - Vol 4 No 1 Mei 2021

e-ISSN 2685-1490; p-ISSN 2615-1472

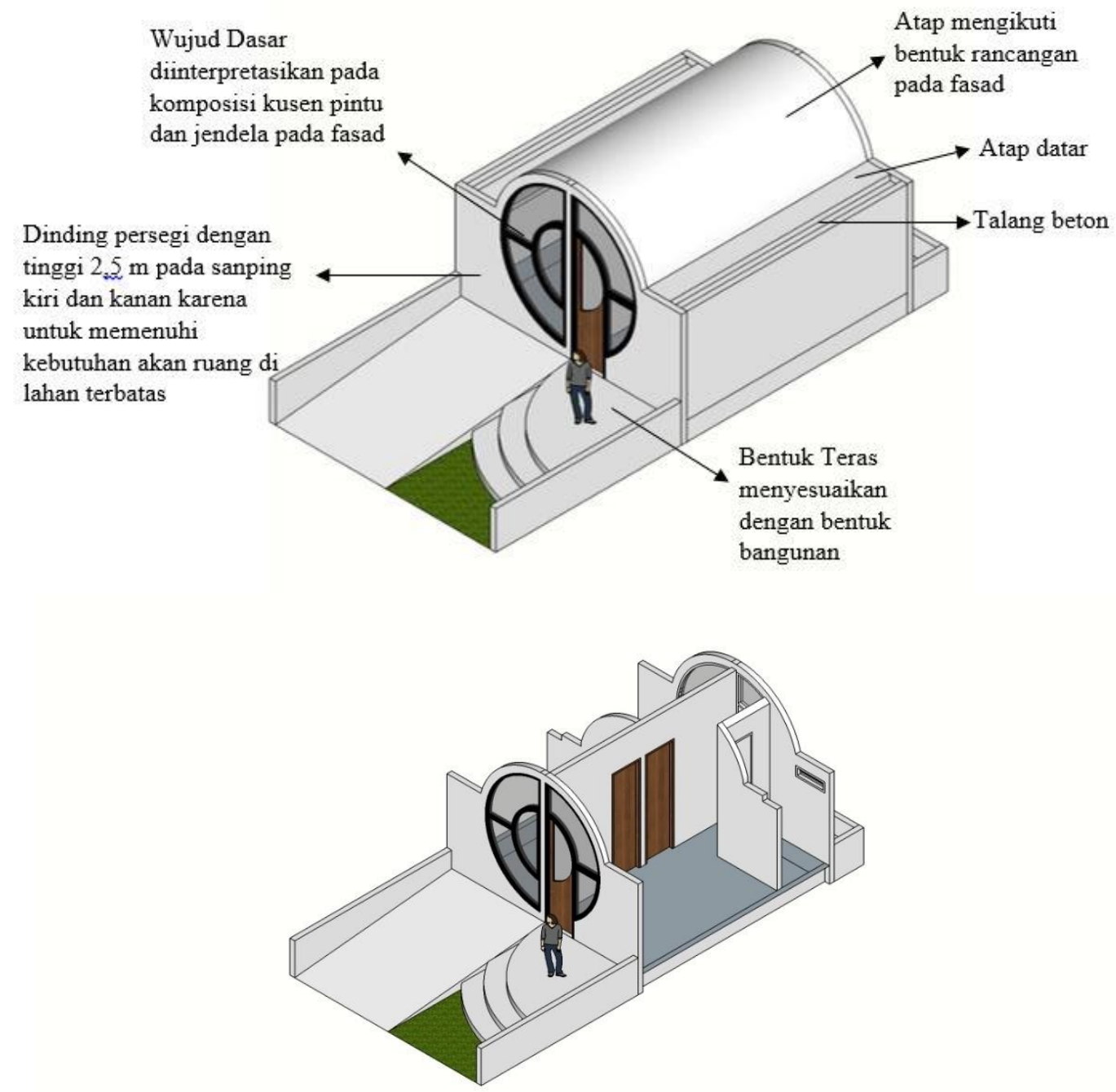

Gambar 6. Isometri L1

Sumber: Peneliti 
Jurnal Arsitektur AIUR - Vol 4 No 1 Mei 2021

e-ISSN 2685-1490; p-ISSN 2615-1472

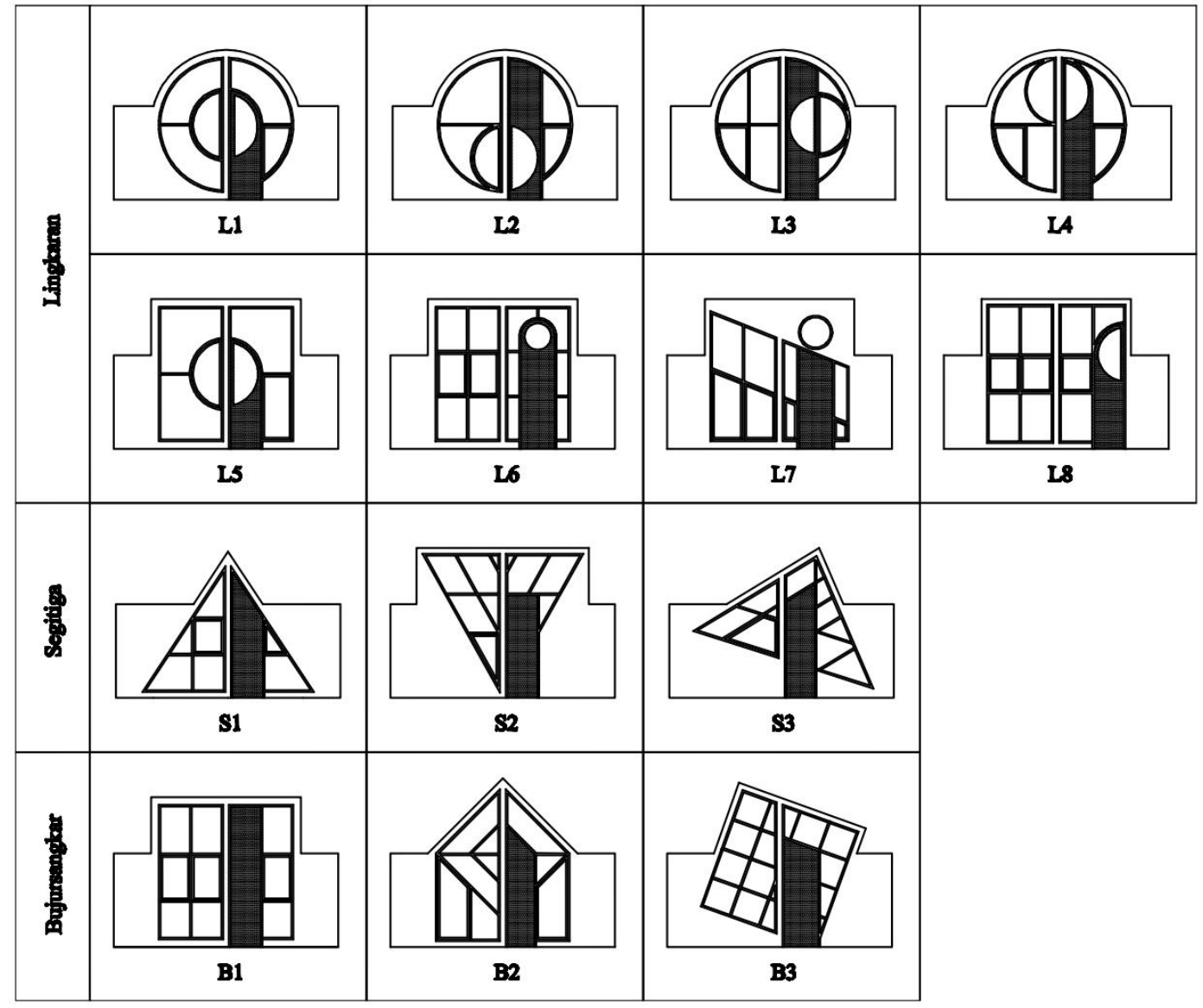

Gambar 7. Hasil Penerapan Wujud Dasar Ching (2000) pada Fasad Rumah Tinggal Tipe 36 Sumber: Peneliti

Pada desain penerapan Wujud Dasar L5-L8, komposisinya adalah wujud lingkaran di dalam bidang bujursangkar. Bujursangkar diinterpretasikan mewujud pada bentuk bangunan, sedangkan lingkaran diinterpretasikan mewujud pada kusen pintu-jendela. Lingkaran dalam pada bidang bujursangkar pada masing-masing desain berada di tengah-tengah, bersifat swa-pusat, bersifat dinamis pada bidang miring di tengah bujursangkar, dan bersifat menetap terpotong sisi-sisi bujursangkar. Posisi pintu-jendela menyesuaikan pada pembagian pada bidang bujursangkar yang bertemu dengan lingkaran di dalam sesuai dengan kubutuhan akan pintu-jendela.

Pada desain penerapan Wujud Dasar S1-S3, komposisi adalah segitiga yang berdiri stabil, segitiga yang berdiri terbalik di satu sudut saja (labil maksimum), dan segitiga yang berdiri di satu sudut saja secara tidak stabil. Wujud segitiga diinterpretasikan mewujud pada bentuk bangunan. Untuk S2, segitiga diinterpretasikan posisinya ada di dalam bentuk bujursangkar dikarenakan kebutuhan akan bentuk tersebut untuk kesederhanaan bentuk yang diharapkan pada obyek rangcang sederhana (rumah tinggal tipe 36). Posisi pintu-jendela menyesuaikan pada pembagian pada wujud segitiga sesuai dengan kubutuhan akan pintu-jendela.

Pada desain penerapan Wujud Dasar B1-B3, komposisi adalah bujursangkar yang berdiri stabil, bujursangkar yang diputar 45 derajat, dan bujursangkar yang berdiri pada salah satu sudutnya secara tidak stabil. Wujud bujursangkar diinterpretasikan mewujud pada bentuk bangunan. Untuk posisi pintu-jendela menyesuaikan pada grid wujud bujursangkar sesuai dengan kubutuhan akan pintu-jendela.

Pada penerapan perbendaharaan desain Wujud Dasar pada Lingkaran, terdapat bentuk kusen jendela lengkung yang memerlukan perlakuan khusus ketika apabila nantinya dilaksanakan secara nyata di proyek konstruksi yang riil, dikarenakan bentuknya yang lengkung. Untuk materialnya, dapat menggunakan aluminium lengkung ataupun kayu. 
Sementara pada Wujud Dasar Segitiga terdapat bentukan bersudut lancip (kurang dari 90 derajat) yang memerlukan perhitungan presisi pada kusen ketika akan dirakit dan dipasang di lapangan. Begitu pula dengan bukaan dari pintu-jendela, memerlukan perhitungan yang presisi agar sesuai pada pertemuan dengan kusen.

Pada Wujud Dasar Bujursangkar, sudut yang dibentuk adalah 90 derajat di mana bentuk tersebut merupakan bentuk yang umum terdapat di proyek konstruksi sehingga tidak memerlukan penyesuaian di dalam pelaksanaannya. Penelitian ini lebih menitikberatkan pada penerapan Wujud Dasar di dalam desain sehingga kurang mempertimbangkan kepraktisan manufaktur di dalam desain, karena untuk mempertimbangkan kepraktisan manufaktur maka diperlukan pengambilan keputusan desain yang berbeda (proporsi).

\section{Kesimpulan dan Saran} berikut:

Kesimpulan sebagai refleksi dari penerapan perbendaharaan desain Wujud Dasar yaitu sebagai

1. Penelitian menggunakan paradigma Konstruksivisme di mana paradigma ini berpandangan bahwa penelitian bersifat subyektif dan juga bahwa pengetahuan bersifat sementara dan berubah-ubah, dan juga terdapat realita dalam jumlah tak terbatas.

2. Wujud Dasar sesuai jika diterapkan di desain rumah tinggal sederhana tipe 36, dikarenakan wujud yang sederhana sesuai dengan obyek rancang yang juga sederhana.

3. Wujud Dasar sesuai untuk diterapkan pada desain fasad rumah tinggal pada blok perumahan menyesuaikan Wujud Dasar lingkaran, segitiga, atau bujursangkar, sehingga sebuah rumah pada perumahan akan bersebelahan dengan rumah dengan Wujud Dasar sama namun dengan alternatif yang berbeda (misal L1 bersebelahan dengan L2 hingga L8, dan S1 bersebelahan dengan S2, dan bersebelahan dengan S3, serta B1 bersebelahan dengan B2 dan B3). Diharapkan akan tercapai variasi dari fasad rumah-rumah tersebut karena memiliki ciri berbeda antar satu rumah dengan rumah di sebelahnya. Hal ini sebagai upaya perbaikan estetika dari perumahan-perumahan pada kondisi empiris di mana rumah yang satu dan lainnya bersebelahan dengan desain yang sama sehingga muncul kesan monoton.

4. Komposisi Wujud Dasar tetap memperhatikan skala dimensi manusia dan juga kebutuhan fungsional seperti kebutuhan pintu, jendela yang dapat dibuka, dan jendela dengan kaca mati, dan juga pemenuhan akan ruang di lahan terbatas, dengan tetap memperhatikan pembagian yang selaras dengan konsep perbendaharaan desain Wujud Dasar dari Ching (2000).

5. Untuk fasad dengan Wujud Dasar lingkaran dan juga segitiga, akan memerlukan penyesuaian dalam hal pelaksanaan riil di lapangan, yaitu pembuatan kusen jendela yang lengkung pada lingkaran dan miring pada segitiga. Selain itu, diperlukan perhatian pada joint antara kusen tersebut dengan bentuk opening yang harus pas. Sebagaimana pembahasan di bagian sebelumnya, berdasarkan metode desain Ching (2000), penelitian ini menitikberatkan kepada penerapan perbendaharaan desain, bukan kepada kepraktisan manufaktur.

Saran untuk penelitian ke depan yaitu:

1. Penelitian berikutnya dapat mengeksplorasi perbendaharaan desain Francis D.K. Ching lebih lanjut pada Arsitektur: Bentuk, Ruang dan Tatanan.

2. Metode desain dapat menggunakan metode Proporsi di mana sesuai dengan pernyataan Jormakka et al (2014) tidak hanya menitikberatkan kepada estetika, namun juga kepada kepraktisan manufaktur.

3. Metode desain yang diterapkan dapat lebih bervariasi disesuaikan dengan keperluan akan penerapan dan konteks.

4. Obyek rancang dapat dibuat lebih sederhana, lebih kompleks maupun berbeda sehingga terdapat variasi dalam hal penerapan/aplikasi perbendaharaan desain.

\section{Ucapan Terima Kasih}

Terima kasih saya haturkan kepada:

1. Dekan Fakultas Teknik Universitas Merdeka Surabaya Bapak Dr. Ir. Eddy Imam Santoso atas dukungannya.

2. Kaprodi Arsitektur Bapak Ir. Komang Kerthajaya, MT. atas dukungannya. 
Jurnal Arsitektur ALUR - Vol 4 No 1 Mei 2021

e-ISSN 2685-1490; p-ISSN 2615-1472

3. Rekan-rekan Dosen di Fakultas Teknik Prodi Arsitektur Universitas Merdeka Surabaya: Bapak Ir. Tokip Susanto, MT., Ibu Tisa Angelia, ST., MT., Ibu Clara Sarti Widiwati, ST., M.Ars., atas kerja tim yang baik.

\section{Daftar Pustaka}

Alexander, C. (1973). Notes on The Synthesis of Form. Massachusetts: John Wiley \& Sons, Inc. Atmadjaja, J. S \& Dewi, M.S. (1999). Estetika Bentuk. Jakarta: Penerbit Gunadarma.

Ballantyne, A. (2002). Architecture: A Very Short Introduction. New York: Oxford University Press.

Ching, F.D.K. (2000). Arsitektur: Bentuk, Ruang dan Tatanan. Jakarta: Penerbit Erlangga.

Crysler C.G, Cairns, S. \& Heynen, H. (2012). The SAGE Handbook of Architectural Theory. London: SAGE Publications Ltd.

Darmawan, E dan Maharani, M.R. (2016). Konsep Perancangan Arsitektur. Jakarta: Penerbit Erlangga.

Groat, L \& Wang, D. (2013). Architectural Research Methods. New Jersey: John Wiley \& Sons, Inc.

Jormakka, K., Schürer, O., Kuhlmann, D. (2014). Basics Design Methods. Basel: Birkhäuser Verlag GmbH.

Julianto, P.A. September 2016. Hingga 2025, Kebutuhan Rumah di Indonesia Tembus 30 Juta Unit, <URL:

https://money.kompas.com/read/2016/09/17/195151226/ hingga.2025.

kebutuhan.rumah.di.indonesia.tembus.30.juta.unit.> 